\title{
Prevalence of subclinical and overt hypothyroidism in infertile women
}

\author{
Niroopama Pushpagiri*, Leila J. Gracelyn, Saranya Nagalingam
}

\author{
Department of Obstetrics \& Gynaecology, A.C.S Medical College and Hospital, Chennai, Tamil Nadu, India
}

Received: 15 October 2015

Accepted: 07 November 2015

\section{*Correspondence:}

Dr. Niroopama Pushpagiri,

E-mail: dr_niroop@yahoo.co.in

Copyright: (C) the author(s), publisher and licensee Medip Academy. This is an open-access article distributed under the terms of the Creative Commons Attribution Non-Commercial License, which permits unrestricted non-commercial use, distribution, and reproduction in any medium, provided the original work is properly cited.

\begin{abstract}
Background: Hypothyroidism has a significant effect on fertility causing anovulatory cycles, luteal phase defect, hyperprolactinemia and sex hormone imbalances. To identify potential and overt hypothyroidism, thyroid screening should be done for all infertile women. The objective of the study was to find the prevalence of subclinical and overt hypothyroidism among infertile women, to find the correlation of hypothyroidism with hormonal and metabolic parameters associated with infertility.

Methods: Hospital based analytical cross sectional study was conducted for one and half years among 300 infertile women with primary and secondary infertility. Women with primary and secondary infertility. All hypothyroid women on thyroxine supplementation, male factor infertility, female factor infertility like tubal factor, anomalies of the urogenital tract, obvious organic lesions in the pelvis and women unwilling to participate or sign the informed consent.

Results: The prevalence of hypothyroidism in infertile women was $27 \%$. Among them, $25 \%$ were subclinical hypothyroid and $2.33 \%$ overt hypothyroid. Menstrual dysfunction was observed in $52 \%$ of subclinical and $51.15 \%$ of overt hypothyroid women, predominant type being oligomenorrhea. We found a negative correlation of hypothyroidism with the family history of thyroid disease. $91.4 \%$ of hypothyroid infertile women were obese and the association was strongly significant. Prevalence of hyperprolactinemia in infertile women was $24.67 \%$. The association of hyperprolactinemia with hypothyroidism was 23\%. Raised LDL levels were observed in $80 \%$ of subclinical and $100 \%$ overt hypothyroidism infertile women.

Conclusions: Hypothyroidism alters the Hypothalamo-Pituitary ovarian axis and is one of the important etiological factors of female infertility. Most of the women were asymptomatic. Hence every infertile woman should be screened for thyroid profile to open better prospects of conception.
\end{abstract}

Keywords: Subclinical hypothyroidism, Overt hypothyroidism, Hyperprolactinemia

\section{INTRODUCTION}

Thyroid dysfunction is one of the important hormonal factors contributing to female infertility. The prevalence of hypothyroidism varies between $2-4 \%$ in women of reproductive age group. ${ }^{1,2}$ It has profound effect on estrogen metabolism, menstrual function and fertility causing anovulatory cycles, luteal phase defect, hyperprolactinemia and sex hormone imbalances. Thyroid evaluation should be done in women who are unable to conceive after 1 year of unprotected intercourse, those with irregular menstrual cycles or recurrent miscarriages or family history of thyroid disorders. Hypothyroidism can be easily detected by estimating thyroid stimulating hormone (TSH) levels in the blood. A slight increase in TSH levels with normal $\mathrm{T}_{3}$ (tri iodothyronine) and $\mathrm{T}_{4}$ (thyroxine) indicates subclinical hypothyroidism $(\mathrm{SCH})$ whereas high $\mathrm{TSH}$ levels with low $\mathrm{T}_{3}$ and $\mathrm{T}_{4}$ levels indicate overt hypothyroidism. $\mathrm{SCH}$ is more common and often asymptomatic. Hypothyroid infertile women are associated with hyperprolactinemia due to increased 
production of thyrotropin releasing hormone (TRH) which further increases the level of TSH as well as prolactin. The aim and objective of the study was to find the prevalence of hypothyroidism in female infertility, associated risk factors and correlation with other hormonal and biochemical factors so that identifying the problem at the earliest and simple oral treatment with LThyroxine would cause a great benefit for hypothyroid infertile patients.

\section{METHODS}

\section{Study design}

Hospital based analytical cross sectional study

\section{Study period}

One and half years from April 2014 to September 2015 .

\section{Study population}

300 women who attend the outpatient department, OBGY, ACS Medical College, Chennai.

\section{Inclusion criteria}

Women with primary and secondary infertility.

\section{Exclusion criteria}

1. All hypothyroid female patients who were on Lthyroxine supplementation.

2. Male factor infertility, female factors like tubal factor, urogenital tract anomalies and obvious organic lesions in the pelvis.

3. Women unwilling to participate or sign the informed consent.

\section{Ethical considerations}

Informed consent was obtained from all the participants at the start of the study. Ethical clearance was taken from the institutional ethical committee before starting the study.

\section{Proforma}

Detailed clinical history was taken and clinical examination performed. Information about age, menarche, menstrual cycles, marital status, clinical features of hypothyroidism, family history of thyroid disease, anthropometric measurements of weight, height, BMI were noted. Semen analysis, USG abdomen and pelvis, hysterosalpingography, premenstrual endometrial sampling, serum TSH and free $\mathrm{T}_{4}$ levels by radio immuno assay (RIA), serum prolactin levels and lipid profile were done.
Regarding hypothyroidism, the women were divided into 3 groups, as per the National Health and Nutrition Examination Survey III 2002. ${ }^{3}$

1. Group 1 (euthyroid): Infertile women with normal TSH level (0.39-4.6 mIU/ml).

2. Group 2 (subclinical hypothyroidism): Infertile women with raised TSH level ranging from 4.6-20 $\mathrm{mIU} / \mathrm{ml}$ and normal free $\mathrm{T}_{4}$ level.

3. Group 3 (overt hypothyroidism): Infertile women with TSH level > $20 \mathrm{mIU} / \mathrm{ml}$ and low free $\mathrm{T}_{4}$ level.

With regard to raised prolactin (PRL) levels, as per WHO guidelines, PRL level > $25 \mu \mathrm{g} / \mathrm{l}$ was considered as hyperprolactinemia. ${ }^{4}$

\section{BMI - ICMR Guidelines (2008) $)^{5}$}

1. Normal - $18-22.9 \mathrm{~kg} / \mathrm{m}^{2}$

2. Overweight $-23-25 \mathrm{~kg} / \mathrm{m}^{2}$

3. Obese - $>25 \mathrm{~kg} / \mathrm{m}^{2}$

In our study, we have analysed the prevalence of hypothyroidism among primary infertile and secondary infertile women, potential demographic risk factors, hormonal and metabolic parameters associated with hypothyroidism

Categorical data were analysed with the odds ratio, chi square test and the $\mathrm{P}$ value of $<0.05$ was considered statistically significant. SPSS software was used for statistical analysis.

\section{RESULTS}

Table 1: Socio - demographic risk profile of infertile women.

\begin{tabular}{|c|c|c|c|}
\hline Variable & $\begin{array}{l}\text { Classification } \\
\text { of variable }\end{array}$ & $\begin{array}{l}\text { No. of pts. } \\
(300)\end{array}$ & $\begin{array}{l}\text { Percentage } \\
\%\end{array}$ \\
\hline \multirow{4}{*}{ Age } & $\geq 18-25$ & 106 & 35.33 \\
\hline & $25-30$ & 128 & 42.67 \\
\hline & $30-35$ & 57 & 19.00 \\
\hline & $>35$ & 9 & 3.00 \\
\hline \multirow{3}{*}{ BMI } & $<23$ & 161 & 53.67 \\
\hline & $23-25$ & 61 & 20.33 \\
\hline & $>25$ & 78 & 26.00 \\
\hline \multirow{2}{*}{$\begin{array}{l}\text { Family } \\
\text { H/o }\end{array}$} & Yes & 25 & 8.33 \\
\hline & No & 275 & 91.67 \\
\hline \multirow{2}{*}{$\begin{array}{l}\text { Altered } \\
\text { Lipid } \\
\text { Profiles } \\
\text { (Raised } \\
\text { LDL) }\end{array}$} & Yes & 69 & 23.00 \\
\hline & No & 231 & 77.00 \\
\hline
\end{tabular}




\section{Thyroid profile and prevalence of subclinical and overt hypothyroidism among infertile women}

Among 300 women with infertility, $73 \%$ of the patients were euthyroid and $27 \%$ ( 82 patients) were hypothyroid with $95 \%$ C.I: $22.29-32.37$ (Figure 1).

The prevalence of subclinical hypothyroidism was $25 \%$ (75 patients) and overt hypothyroidism was $2.33 \%$ ( 7 patients) which suggests that $\mathrm{SCH}$ was more common than overt hypothyroidism among infertile hypothyroid group.

The percentage of SCH and overt hypothyroidism women among primary infertile group were $27.62 \%$ and $2.51 \%$ and among secondary infertile group were $14.65 \%$ and $1.64 \%$ respectively. This data shows that hypothyroidism was observed relatively more common in primary infertile women (Figure-2).

Table 2: Clinical and biochemical profile of infertile patients.

\begin{tabular}{|llll|}
\hline Variables & Number & Percentage & $\begin{array}{l}95 \% \\
\text { CI }\end{array}$ \\
$\begin{array}{|llll|}\text { Hypothyroidism } \\
\text { (TSH > 4.6) }\end{array}$ & \multirow{2}{*}{82} & 27.33 & $\begin{array}{l}22.29- \\
32.37\end{array}$ \\
\hline $\begin{array}{l}\text { Anovulatory } \\
\text { menstrual cycles }\end{array}$ & 74 & 24.67 & $\begin{array}{l}19.79- \\
29.55\end{array}$ \\
\hline Obesity & \multirow{2}{*}{78} & 26 & $\begin{array}{l}21.04- \\
30.96\end{array}$ \\
\hline Hyperprolactinemia & 74 & 24.67 & $\begin{array}{l}19.79- \\
29.55\end{array}$ \\
\hline $\begin{array}{l}\text { Altered Lipid } \\
\text { Profile }\end{array}$ & \multirow{2}{*}{69} & 23 & $\begin{array}{l}18.24- \\
27.76\end{array}$ \\
\hline
\end{tabular}

\section{Socio-demographic factors of infertile women}

Age

Most of the study subjects belong to the age group of 25 $30 y r s(42.67 \%)$ followed by $18-25$ yrs $(35.33 \%), 30-35$ yrs $(19 \%)$ and $>35 \mathrm{yrs}(3 \%)$. Women of $<25 \mathrm{yrs}$ of age group had 1.25 fold increased risk of hypothyroidism in our study (Odds' ratio [OR] $1.25 ; 0.74-2.11$ ) but this demographic variable was not found to be a risk factor for hypothyroidism $(\mathrm{P}=0.49)$ as seen in Table 3 .

\section{Family history of Thyroid dysfunction}

$8.33 \%$ (25 patients) of infertile women (Table 1) showed positive family history of thyroid disorder. Among hypothyroid group, only 2 patients out of $82(2.67 \%$ subclinical, nil-overt hypothyroidism patients) were having family history of thyroid dysfunction.

In contrary to the various studies which shows that family history is one of the risk factors for hypothyroidism, our statistics showed a negative correlation between family history of thyroid disease and hypothyroidism (OR 4.72; 95\% C.I - 1.09 -20.48) which was statistically significant $(\mathrm{P}=0.04)$ as seen in Table -3 .

\section{BMI and obesity}

$26 \%$ of the study group (95\% C.I: 21.04 - 30.96) were obese (BMI >25). We found a high incidence of obesity 91.4\% (75 patients out of 82) among hypothyroid women with a strong correlation (OR - 767.86 (193.60 3045.56)) and a statistically significant $P$ value 0.0000000 (Table 3).

\section{Menstrual dysfunction}

$24.67 \%$ of infertile women were found to have irregular menstrual cycles. Among hypothyroidism group, 52\% of subclinical hypothyroid women had menstrual dysfunction, most common being oligomenorrhea $(33.33 \%)$ followed by menorrhagia $(18.67 \%)$. In overt hypothyroidism group, irregular cycles were observed in $51.15 \%$, principle menstrual abnormality being oligomenorrhea $(28.57 \%)$ followed by menorrhagia (14.29\%) and amenorrhea (14.29\%). Among the euthyroid infertile women, only $14.22 \%$ had menstrual dysfunction (Figure-2). A strong positive correlation of menstrual dysfunction/anovulatory cycles and hypothyroidism with OR - 6.65; 95\% C.I: $3.74-11.84$ was found with a statistically significant $\mathrm{P}$ value $(0.0000000)$ as seen in Table 3.

\section{Prolactin levels}

Hyperprolactinemia ( $>25 \mathrm{mg} / \mathrm{ml}$ ) was observed in 24.67 $\%$ (74 out of 300 patients) of the study population with 95\% C.I: $19.79-29.55$ (Table 2). When the correlation of raised prolactin levels and hypothyroidism women was analysed, 23\% (19 out of 82 patients) of hypothyroid women were found to have hyperprolactinemia. The above data suggests that not only women with hypothyroidism, but also euthyroid women with infertility were associated with hyperprolactinemia. Statistical analysis in our study showed that hypothyroidism was 1.2 times common in women with normal prolactin levels than in women with hyperprolactinemia. (OR - 1.19; 95\% C.I: 0.62 -2.03) and the statistical correlation of hypothyroidism with raised PRL was insignificant. $(\mathrm{P}=0.83)$

\section{Altered lipid profile}

Hypothyroidism is associated with hyperlipidemia. When we studied the association of raised LDL levels with the study group, $23 \%$ of women $(18.24-27.76)$ had raised LDL levels. Among hypothyroidism group, raised LDL levels were observed in $80 \%$ of subclinical and $100 \%$ of overt hypothyroidism patients. Strong association of hyperlipidemia with hypothyroidism was observed with OD - 482.4; 95\% C.I: 107.57 - 2163.43 having a highly significant $\mathrm{P}$ value of 0.0000000 (Table 3). 


\section{DISCUSSION}

Hypothyroidism is one of the important endocrinological disorders causing ovulatory dysfunction and infertility in reproductive age group women. Most of the subjects in the study group belonged to 20 - 30 years of age.

Various studies have been conducted regarding the prevalence of hypothyroidism in infertile women. Indu Verma et al study on 394 infertile women showed $23.9 \%$ (94 patients) prevalence of hypothyroidism in which $\mathrm{SCH}$ and overt hypothyroidism were $15 \%$ (59) and $8.8 \%(35$ patients) respectively. ${ }^{6}$ In Dilruba Rahman et al study on 30 subfertile women, the proportion of women suffering from hypothyroidism was $33.3 \%$ (SCH - 26.7\%, overt hypothyroidism - 6.7\%). ${ }^{7}$ In Mohana Priya et al study on 98 infertile women, $53.7 \%$ were hypothyroid (50.5\% SCH and $3.2 \%$ - overt hypothyroidism) ${ }^{8}$ Raber's W et al study showed $\mathrm{SCH}$ in $34 \%$ of infertile women and in Bals-Pratsch $\mathrm{M}$ et al study it was $25 \% .{ }^{9,10}$ In our study, the prevalence of $\mathrm{SCH}$ was $25 \%$ (75 patients) and overt hypothyroidism was $2.33 \%$ (7 patients).

Table 3: Correlation between clinical, demographic and biochemical characteristics in infertile patients and subclinical and overt hypothyroidism.

\begin{tabular}{|c|c|c|c|c|c|}
\hline Variable & $\begin{array}{l}\text { Classification of variable } \\
\text { (Total number in the group) }\end{array}$ & $\begin{array}{l}\text { No. of SCH } \\
\text { and overt } \\
\text { hypothyroidism }\end{array}$ & $\begin{array}{l}\text { Chi- } \\
\text { square } \\
\text { value }\end{array}$ & $\begin{array}{l}\text { Odds ratio } \\
\text { (95\% C.I of } \\
\text { odds ratio) }\end{array}$ & P value \\
\hline Age & $\begin{array}{l}\leq 25 \text { years }(106) \\
>25 \text { years }(194)\end{array}$ & $\begin{array}{l}32 \\
50\end{array}$ & 0.47 & $\begin{array}{l}1.25 \\
(0.74-2.11)\end{array}$ & 0.49 \\
\hline $\begin{array}{l}\text { Family history of } \\
\text { thyroid disorders }\end{array}$ & $\begin{array}{l}\text { No }(275) \\
\text { Yes (25) }\end{array}$ & $\begin{array}{r}80 \\
2\end{array}$ & 4.13 & $\begin{array}{l}4.72 \\
(1.09-20.48)\end{array}$ & $0.04 *$ \\
\hline Obesity & $\begin{array}{l}\text { Yes (78) } \\
\text { No (222) }\end{array}$ & $\begin{array}{c}75 \\
7\end{array}$ & 250.51 & $\begin{array}{l}767.86 \\
(193.60- \\
3045.56)\end{array}$ & $0.0000000 *$ \\
\hline Anovulation & $\begin{array}{l}\text { Yes (74) } \\
\text { No ( 226) }\end{array}$ & $\begin{array}{l}43 \\
39\end{array}$ & 44.3 & $\begin{array}{l}6.65 \\
(3.74-11.84)\end{array}$ & $0.0000000 *$ \\
\hline Prolactin levels & $\begin{array}{l}\text { Normal ( } 226) \\
\text { Increased ( } 74)\end{array}$ & $\begin{array}{l}63 \\
19 \\
\end{array}$ & 0.05 & $\begin{array}{l}1.19 \\
(0.62-2.03)\end{array}$ & 0.83 \\
\hline $\begin{array}{l}\text { Altered Lipid } \\
\text { profile } \\
\text { (Raised LDL) }\end{array}$ & $\begin{array}{l}\text { Yes (69) } \\
\text { No (231) }\end{array}$ & $\begin{array}{l}67 \\
15\end{array}$ & 219.6 & $\begin{array}{l}482.4(107.57 \\
-2163.43) \\
(0.62-2.03) \\
\end{array}$ & $0.0000000^{*}$ \\
\hline
\end{tabular}

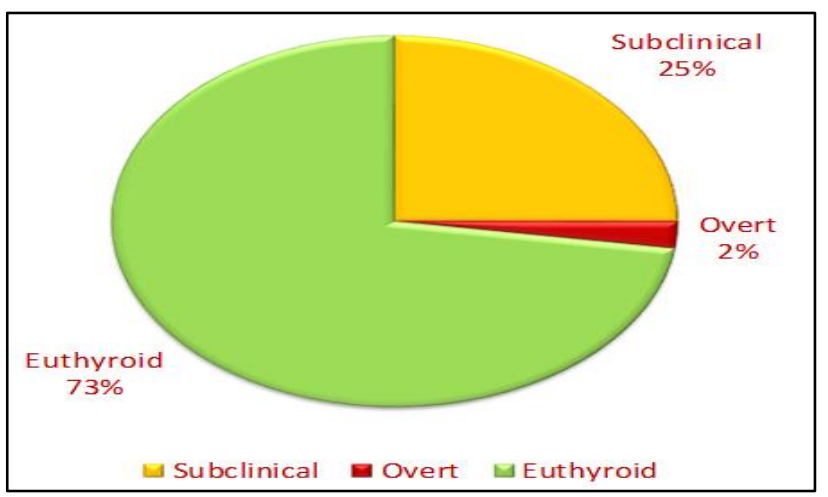

Figure 1: Prevalence of hypothyroidism among infertile women.

Most of the studies and literature review suggest that the prevalence of $\mathrm{SCH}$ was more common than overt hypothyroidism among infertile women. $\mathrm{SCH}$ may progress to overt hypothyroidism and the rate of progression. The rate of progression would be higher among women with higher levels of TSH or presence of TPO-Ab. ${ }^{1}$ Even though there was a controversy regarding treatment of $\mathrm{SCH}$, maintaining $\mathrm{TSH}$ levels at the lower end of normal may improve the pregnancy rates among infertile women and reduce the risk of miscarriages.

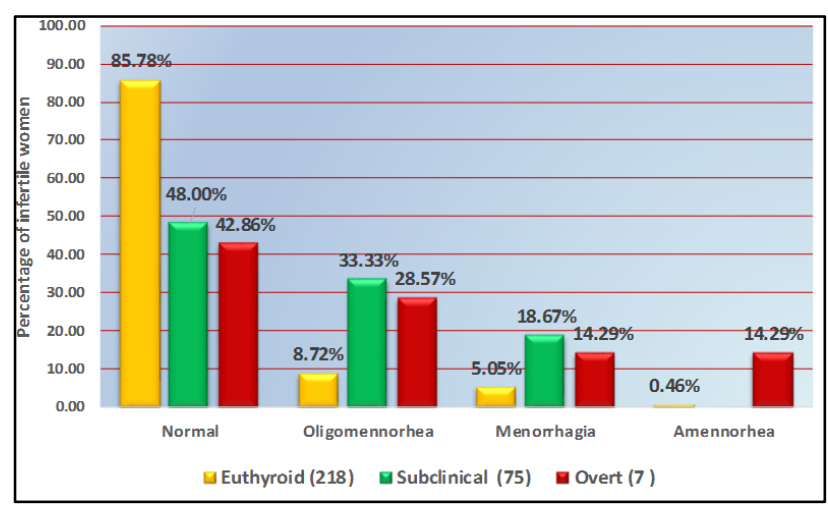

Figure 2: Menstrual patterns in infertile women.

Anovulatory cycles were very common in hypothyroid infertile women. In Acharya Neema et al study, 60.87\% of subclinical hypothyroid women (oligomenorrhea - 
$28.2 \%$, menorrhagia $-17.39 \%$ ) and $52.95 \%$ of overt hypothyroid women had menstrual dysfunction (oligomenorrhea - 23.5\%, menorrhagia -17.64\%). ${ }^{12}$ In another study conducted by Joshi et al, prevalence of menstrual abnormality was found to be $68 \%$ among 22 hypothyroid patients, mainly oligo/hypomenorrhoea even though all types of bleeding abnormalities were present, In Krassas et al study, 23\% among 171 hypothyroid patients had menstrual dysfunction, predominantly oligomenorrhea and less commonly secondary amenorrhea. $^{13,14}$ In our study, $52 \%$ of subclinical, $51.15 \%$ of overt and $14.22 \%$ of euthyroid women had menstrual dysfunction, predominant type being oligomenorrhea (Figure 2).

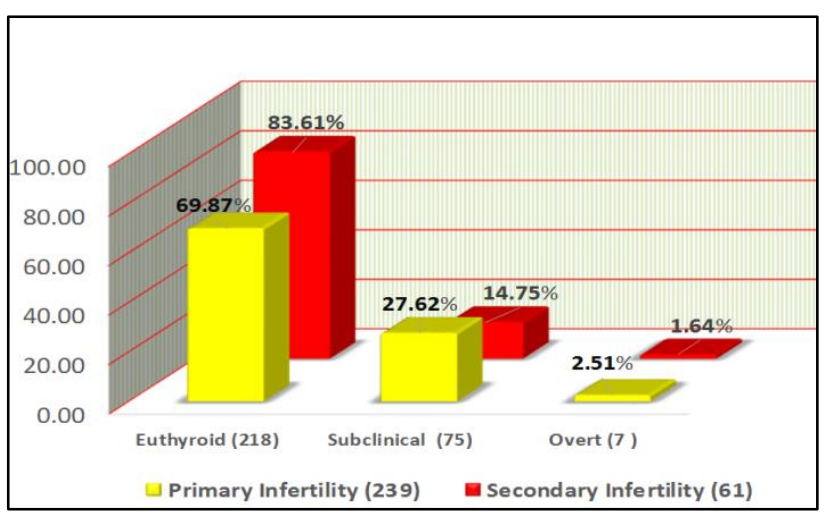

Figure 3: TSH values in patients with primary and secondary infertility.

The relation between hypothyroidism and menstrual dysfunction was mediated by increase in thyrotropinreleasing hormone (TRH) thus interfering the regulation of ovarian function. In addition it alters the peripheral metabolism of oestrogen by decreasing sex hormonebinding globulin production, increase in prolactin levels and altered GnRH pulsatile secretion causing inadequate corpus luteum due to delay in LH response contributing to anovulation.

Subclinical and overt hypothyroidism is frequently associated with weight gain, decreased thermogenesis, and metabolic rate. In Mario Rotondi et al study on hypothyroidism associated with obesity, subclinical hypothyroidism was observed in $13.7 \%$ obese patients. ${ }^{15}$ Verma et al study on 625 hypothyroid patients found $34 \%$ (26) obesity among 77 subclinical hypothyroid patients and 46\% (252) obesity among 548 overt hypothyroid patients. ${ }^{16}$ In our study, 69 out of $72(92 \%)$ subclinical hypothyroid patients and 6 out of 7 overt hypothyroid patients $(82.71 \%)$ were obese.

As hypothyroidism is related to obesity, to avoid obesity related metabolic changes (hypertension, dyslipidemia, insulin resistance), in such patients, apart from thyroid hormone therapy, life style interventions should be advised.
Hypothyroidism is associated with hyperprolactinemia. In Indu Verma et al study on 394 infertile women for the prevalence of hypothyroidism, 54 women $(13.7 \%)$ were having hyperprolactinemia and 18 patients $(4.57 \%)$ had both hypothyroidism and hyperprolactinemia. ${ }^{6}$ Binita Goswami et al study on 160 women with primary infertility showed hyperprolactinemia in $41 \%$ of infertile women and $46.1 \%$ of hypothyroid women were associated with hyperprolactinemia. ${ }^{17}$ The underlying mechanism for raised PRL levels is, hypothyroidism stimulates the production of TRH which is associated with increased production of TSH and prolactin. Hyperprolactinemia impairs GnRH pulsatality leading to anovulation and infertility. In our study, $24.67 \%$ of infertile women had raised prolactin levels and $23 \%$ of women were having hypothyroidism associated with hyperprolactinemia.

The data suggests that it is important to estimate both serum TSH and prolactin levels in the infertility work up. In hypothyroid infertile women associated with hyperprolactinemia, before evaluating further causes of raised PRL levels, the first treatment should be to correct the hypothyroidism.

Hypothyroid women are at risk of hyperlipidemia. Significant increase in LDL oxidation occurs in hypothyroid patients, the degree of which is directly related to the serum LDL cholesterol concentration. A study conducted by Zha $\mathrm{K}$ et al on LDL in patients with $\mathrm{SCH}$ found that serum LDL-C level were higher in $\mathrm{SCH}$ group than in euthyroid group $(\mathrm{P}<0.05) .{ }^{18}$ Staub et al study on euthyroid (52) and hypothyroid women (SCH 69, overt hypothyroidism - 17) observed an elevated serum LDL cholesterol levels in $42.9 \%$ of patients with hypothyroidism compared with $11.4 \%$ in control group. ${ }^{19}$ In our study, $23 \%$ of infertile women had raised LDL levels. Among hypothyroid infertile patients, $80 \%$ of subclinical and $100 \%$ of overt hypothyroid patients had raised LDL levels.

\section{CONCLUSION}

The prevalence of hypothyroidism in infertile women is much higher than in women with reproductive age group. Subclinical hypothyroidism is more prevalent than overt hypothyroidism. Menstrual dysfunction and the proportion of obese women were found to be significantly high in the study. Screening for hypothyroidism is extremely important so that treatment with thyroxine can be started at the earliest so as to maintain TSH levels at the lower limit in the management of subfertility and recurrent miscarriages. As hypothyroidism is associated with hyperprolactinemia, measurement of PRL should also be done as a part of infertility work up and correction of hypothyroidism should be done first. Hyperlipidemic patients with hypothyroidism should be treated with thyroxine as restoration of euthyroidism can effectively improves the lipid levels. 
Funding: No funding sources

Conflict of interest: None declared

Ethical approval: The study was approved by the Institutional Ethics Committee

\section{REFERENCES}

1. Wang C, Crapo LM. The epidemiology of thyroid disease and implications for screening. Endocrinology and Metabolism Clinics of North America. 1997;26:189-218.

2. Bjoro T, Holmen J, Kruger O, Midthjell K, Hunstad $\mathrm{K}$, Schereiner T, et al. Prevalence of thyroid disease, thyroid dysfunction and thyroid peroxidae antibodies in a large, unselected population. The health Study of Nord-trondelag (HUNT). European Journal of Endocrinology. 2000;143:639-47.

3. Garber JR, Cobin RH, Gharib H, Hennnessey JV, Klein I, Mechanick JI, et al. Clinical practice guidelines for hypothyroidism in adults: cosponsored by the American Association of Clinical Endocrinologists and the American Thyroid Association. Endocr. Pract. 2012:18:988-1028.

4. Melmed S, Casanueva FF, Hoffman AR, Kleinberg DL, Montori VM, Schlechte JA, et al. Diagnosis and treatment of hyperprolactinemia: an Endocrine Society clinical practice guideline. J Clin Endocrinol Metab. 2011;96:273-88.

5. Misra A, Chowbey P, Makkar BM, Vikram NK, Wasir JS, Chadha D. Consensus statement for diagnosis of obesity, abdominal obesity and the metabolic syndrome for Asian Indians and recommendations for physical activity, medical and surgical management. J Assoc. Physicians India. 2009;57:163-70.

6. Verma I, Sood R, Juneja S, Kaur S. Prevalence of hypothyroidism in infertile women and evaluation of response of treatment for hypothyroidism on infertility. Int J Appl Basic Med Res. 2012;2(1):17-9.

7. Rahman D, Fatima P, Banu J. Thyroid disorders in female subfertility. JCMCTA. 2008;19(2):46-50.

8. Mohana Priya D, Akhtar N, Ahmad J. Prevalence of hypothyroidism in infertile women and evaluation of response of treatment for hypothyroidism on infertility. Indian Journal of Endocrinology and Metabolism. 2015;19(4):504-6.

9. Raber W, Nowotny P, Vytiska-Binstorfer E, Vierhapper $H$. Thyroid treatment modified in Infertile women according to thyroxine releasing hormone testing; 5 years follow-up of 283 women referred after exclusion of absolute causes of infertility, Human Reproduction. 2003;18(4);707-14.
10. Bals-Pratsch M, Muller T, Frieling U, Lerchie A, Pirke KM, Hanker JP, et al. Episodic variations of prolactin, thyroid-stimulating hormone, luteinizing hormone, melatonin and cortisol in infertile women with subclinical hypothyroidism. Human reproduction. 1997;12(5);896-904.

11. Vanderpump MP, Tunbridge WM, French JM, et al. The incidence of thyroid disorders in the community: a twenty-year follow-up of the Whickham Survey. Clin Endocrinol (Oxf). 1995;43:55-68.

12. Neema A, Sourya A, Samarth S, Inamdar SA, Khatri M, Mahajan SN. Gonadotropin levels in Hypothyroid women of Reproductive Age group. The Journal of Obstetrics and Gynaecology of India. 2011;61(5):550-3.

13. Joshi JV, Bhandarkar SD, Chadha M, Balaiah D, Shah R. Menstrual irregularities and lactation failure may precede thyroid dysfunction or goitre. Journal of Postgraduate Medicine. 1993;39:137-41.

14. Krassas GE, Pontikides N, Kaltsas T, Papadopoulou P, Paunkovic J, Paunkovic N. Disturbances of menstruation in hypothyroidism. Clinical Endocrinology. 1999;50:655-9.

15. Rotondi M, Leporati P, La Manna A, Pirali B, Mondello T, Fonte R. Raised serum TSH levels in patients with morbid obesity: is it enough to diagnose subclinical hypothyroidism? European Journal of Endocrinology. 2009;160:403-8.

16. Verma A, Jayaraman M, Modi KD. Hypothyroidism and obesity Cause or Effect? Saudi Med J. 2008;29(8).

17. Goswami B, Patel S, Chatterjee M, Saxena A. Correlation of Prolactin and Thyroid hormone concentration with menstrual patterns in infertile women. Journal of Reprod Infertil. 2009;10(3):20712.

18. Zha K, Zuo C, Wang A, Zhang B, Zhang Y, Wang $B$, et al. LDL in patients with subclinical hypothyroidism shows increased lipid peroxidation. Lipids Health Dis. 2015;14(1):95.

19. Staub J, Althaus B, Engler H, Ryff A, Trabucco P, Marquardt K, et al. Spectrum of subclinical and over hypothyroidism: effect on thyrotropin, prolactin, and thyroid reserve, and metabolic impact on peripheral target tissues. Am J Med. 1992;92(6):631-42.

Cite this article as: Pushpagiri N, Gracelyn LJ, Nagalingam S. Prevalence of subclinical and overt hypothyroidism in infertile women. Int J Reprod Contracept Obstet Gynecol 2015;4:1733-8. 